\title{
The Relationship between Logical, Naturalist Intelligences and Learning Grammar for EFL Learners at Elementary Level
}

\author{
Zeinab Zahedi \\ Department of English Language and Literature, Ferdowsi University, Mashhad, Iran \\ Zargham Ghabanchi \\ Department of English Language and Literature, Ferdowsi University, Mashhad, Iran
}

\begin{abstract}
The present study was an attempt to investigate the existence of any possible relationship among two types of multiple intelligences (logical and naturalist) and learning grammar on EFL males and females in elementary level. An initial number of thirty participants (ten males, twenty females), studying Interchange Intro book in Golestan language institute of Mashhad, took part in the study. The data was collected through 119-item multiple intelligences test and 40-item grammar test. In order to analyze the data, the Pearson Correlation Coefficient was used. It was found that there is a strong relationship among the scores of mentioned intelligences and learning grammar among male students whereas no relationship was observed among females
\end{abstract}

Index Terms-Multiple Intelligences Theory (MIT), learning grammar, Foreign Language Learners (EFL learners)

\section{INTRODUCTION}

The system of teaching and learning foreign languages in Iran has been changed a lot in comparison with the period fifteen or twenty years ago.

Gone are the times when the way of teaching was based only on reading and doing grammar exercises in each lesson of the textbook. Since those times, there have really been very significant changes in the approach of teaching foreign languages.

There is also a great choice of teaching aids and various supplementary materials, so all teachers can choose what textbooks, methods or activities would be the most convenient for their learners. Nevertheless, it can sometimes be difficult to find an approach that would be suitable for all the pupils within one classroom.

Since the introduction of the multiple intelligences theory (MIT) in Gardner's book (1983), interest has been growing internationally in examining the role of multiple intelligences (MI) in learning, achievement, and knowledge acquisition.

Gardner (1983) suggests the existence of nine relatively autonomous, but interdependent intelligences rather than just a single construct of intelligence. He defines the concept of intelligence as the ability to solve problems or fashion products that are of consequence in a particular cultural setting or community. (Gardner, 1993, p. 15)

This study will handle both theories about multiple intelligences and grammar. Moreover, it tries to understand whether there is a relationship between these two items or not.

\section{LITERATURE REVIEW}

\section{A. Historical Overview of Intelligence Studies}

"An intelligence is the ability to solve problems, or create products, that are valued within one or more cultural settings". Howard Gardner, Frames of Mind (1983).

'the idea of intelligence was first put forward by Francis Galton in 1885, who used statistical tools and curves to show the relationship between heredity and being genius (Chaplin and Krawiec, 1974). However, he could not form a standardized intelligence test. It helped other researchers like Alfred Binet to create a method for distinguishing students with learning difficulties by the request of French ministry of education in 1904. After one year, by receiving assistance from Simon (another French psychologist), Binet formed the first intelligence test in 1905. Although the test had some shortcomings, it was welcomed by educationalist and gained publicity as the IQ test (Gardner, 1985).

During 1920, E.L Thorndike proposed a view that the brain is like a muscle which can be more and more powerful by exercise. He assumed that studying challenging subjects like mathematics and Latin can empower students learning ability. He designed a test to measure individuals linguistic and mathematical abilities that eventually became the foundation of modern intelligence tests. 
Spearman (1923), formed a new idea about the general factor of intelligence which became known as the " $\mathrm{g}$ " factor. Thus, he designed some tests for measuring intelligence which were intended to be naturally scientific (Gardner, 1983).

In 1970 s, Piaget divided human intelligence into two parts; operative intelligence which explains how the world is understood, and figurative intelligence which is responsible for the representation of reality (see Gardner, 1985)

Regarding IQ tests, Sternberg (1982) declared that the validity of these tests varies across examinees. He states that intelligence is the ability for adapting ones behavior to the environment and situation. The same researcher, 1985, also proposed a triarchic theory of intelligence. Componential ability, experiential ability, and contextual ability. By the first one he means analytical thinking, by the second one he means creative thinking, and by the last one he means the ability to manipulate context and situation (Sternberg, 1985).

In 1983 Gardner criticized the traditional IQ tests as incompatible with his multiple intelligences (MI) theory. He proposed several intelligences to be at work simultaneously. And, thus, changed the perception through training and practice.

In Gardner's (1983) point of view, intelligence is a combination of different abilities, he divides human intelligence into Linguistic, Logical- Mathematical, Spatial, Musical, Bodily- Kinesthetic, Interpersonal, Intrapersonal, Naturalistic and Existential intelligences. Gardner believes that it is important to identify each individual as a collection of aptitudes (p. 27) rather than being identified by a single IQ measure.

\section{B. Criteria for Determining an Intelligence}

Gardner (as cited in Ahmadian\& Hosseini, 2012) presented a series of eight separate criteria to determine an intelligence.

\section{Isolation by brain damage}

This factor means that one intelligence can be separate from others. People are believed to have multiple intelligences because they have multiple neural modules which have different ways of working and memory system (Ahmadian \& Hosseini, 2012). When people suffer from brain damage, one intellectual skill may be sometimes spoiled while other skills remain. To illustrate, musicians who have brain injury may have impaired speech but they are able to play music (Hodges. 1996). That is to say, since an individual can lose ability in one area while others are spared, there is impossible to be existent a single intelligence. (Ahmadian\& Hosseini, 2012).

\section{Evolutionary history}

As cited in Ahmadian, \& Hosseini, (2012) Each intelligence proves a significant part during the evolutionary history of human being as well as shows its ability to face with the environment. In this case, spatial ability was believed to be essential to the man survival, particularly on the way to find out different terrains. (Ahmadian\& Hosseini, 2012).

\section{The presence of core operations}

An intelligence is thought to have an identifiable core set of operations, for example, the core operations of musical intelligence are timbre, harmony, rhythm and pitch. (as cited in Ahmadian\& Hosseini, 2012).

\section{Susceptibility to encoding}

An intelligence has to be susceptible to encode in a symbol system to exactly and systematically express information. Several instances of encoding are written and spoken language a distinctive developmental history. (as cited in Ahmadian\& Hosseini, 2012).

\section{A distinctive developmental history.}

As cited in Ahmadian\& Hosseini, 2012, different intelligences have different developmental history. This difference is clearly shown in its time of arising, its time of peaking, and its time of declining. It is said that, for example, musical intelligence peaks early while linguistic intelligence peaks very late. (as cited in Ahmadian\& Hosseini, 2012)

\section{The existence of exceptional individuals.}

Some individuals like prodigies are regarded as accidents of nature. Another instance of extraordinary intelligence is the autistic person who excels at numerical calculation or musical performance. (Ahmadian \& Hosseini, 2012).

\section{Psychological tasks}

Experimental psychology is supported to show the relation between two operations. Having a look at people demonstrating two activities at the same time can lead to identify if those activities depend on the same mental capacities or different ones. (as cited in Ahmadian\& Hosseini, 2012)as an illustration, a person doing a crossword puzzle cannot effectively talk since both these are related to linguistic intelligence. Whereas, one can take a walk and carry on a conversation simultaneously because two different intelligences take part in these tasks. (Ahmadian\& Hosseini, 2012).

\section{Psychometric findings}

Many standardized tests support the multiple intelligences theory such as the Weschsler (1896) Intelligence Scale for Children- Revised test. (as cited in Ahmadian\& Hosseini, 2012). In other words, when introducing these criteria, Gardner desired to make a clear distinction between an intelligence and a talent or skill. These eight criteria were supported by biological sciences developmental psychology, logical analysis as well as traditional psychological research (Gardner, 1999 as cited in Ahmadian\& Hosseini, 2012).

According to these criteria, Gardner suggests and identifies eight Intelligences in his MI theory:

C. The Description of Nine Intelligences 


\section{Verbal- linguistic intelligence.}

People who have high linguistic intelligence are able to use words and language. They can also understand others. They can learn other languages as well. Students who have this intelligence love to read, write and use words in games and memorize things.

\section{Math- logical intelligence}

Logical/ mathematical intelligence refers to the ability to understand principles and rules, the way a scientist can manipulate numbers, quantities, and operations, or the way the mathematician does.

It is the capacity to use numbers effectively and reason well. (Pishghadam \& Moafian, 2008). Students who have this intelligence are good problem- solvers. They learn best by putting new information into patterns or relationships, or by putting it into mathematical context. (Gardner, 1983)

\section{Visual- spatial intelligence}

The ability to perceive the visual- spatial world accurately and to think based on the images in mind. Spatially intelligence students are those who enjoy working with maps, diagrams and puzzles. They learn best if new information is presented in the form of a picture, either physical picture they can look at, or mental picture they can visualize and by drawing.

\section{Musical-auditory intelligence}

Musical intelligence refers to the capacity to think in music, to be able to hear patterns, recognize them, remember, and perhaps use them. People who have a strong musical intelligence remember the music easily and everything which has been presented by music.

\section{Bodily- kinesthetic intelligence}

Bodily- kinesthetic intelligence refers the capacity to use your whole body or parts of your body, your hand your fingers, your arms- to talk or make some kinds of production. These kinds of people can express themselves through body gestures.

\section{Interpersonal Intelligence}

Interpersonal intelligence refers to understanding of other people the ability to perceive and make distinctions in the moods, intentions, motivations and feelings of other people.

\section{Intrapersonal Intelligence}

Intrapersonal intelligence refers to understanding of yourself, of knowing who you are what you can do. These kinds of people can perceive their weak and strong points and internal feelings.

\section{Naturalist Intelligence}

Naturalist intelligence refers to the human ability to discriminate among living things such as plants and animals as well as sensitivity to other features of the natural world such as clouds, mountains and rock configuration.

\section{Existential Intelligence}

Refers to human desire to understand and pursue the ultimate question, meanings and mysteries of life. Students who are thinking broadly about existence, purpose of living etc.

\section{Grammar}

We want you to start thinking about what exactly we mean by a term like 'grammar'.

What is grammar? According to Fromkin (1990) as cited in Nachiengmai, 1997, 'The sounds and sound patterns, the basic units of meaning such as words and the rules to combine them to form new sentences constitute the grammar of a language .these rules are internalized and subconsciously learned by native speakers'. Grammar includes many aspects of linguistic knowledge such as sound system (phonology), the system of meaning (semantics), the rules of word formation (morphology), the rules of sentence formation (syntax), and the vocabulary of words (lexicon).

\section{Different views toward grammar}

As cited in Nachiengmai, 1997, there has been a great change in the way grammar is taught and viewed since there has been a movement from Audiolingualism toward communicative approach in teaching . Before, grammar was taught prescriptively; now teachers have tried to consider it in terms of its descriptive aspects as well as cited in Nachiengmai, 1997. As Garner (1989) stated in Nachiengmai, 1997, descriptive grammar is a systematic way of approaching the study of linguistic facts while prescriptive grammar is a means to maintain linguistic excellence. Similarly Fromkin (1990) contrasts descriptive and prescriptive grammars in the sense that while descriptive grammar the already existing rules which represent the unconscious linguistic knowledge or capacity of its speakers, prescriptive grammar tries to preserve what is assumed to be the standard language by telling people what rules they should know and how they should speak and write as cited in Nachiengmai, 1997. Therefore according to prescriptivists as cited in Nachiengmai, 1997, grammar teaching is seen as establishing the correct way of speaking and writing. Secondly, with the communicative approach in which language is viewed as an instrument of communication, it has become clear in language teaching that grammar is viewed as a tool or resource to be used in conveying meaning and comprehending other peoples messages. Unlike the traditional repetitive grammar exercises the past- which tended to focus only on the structures, or as Celce- Murcia (1991) points out the focus of instruction rarely moved beyond the sentence level as cited in Nachiengmai, 1997. These days, more and more teachers try to pay attention to the spoken language although they are also aware of the significance of teaching grammar within context, using meaningful and purposeful communicative approaches. 
As cited in Nachiengmai, 1997, in the last decade, however, grammar instruction had been considered by many teachers as having little or no place in a communicative classroom and this idea was primarily initiated by Krashen (Krashen \& Terrell, 1983); But nowadays, we see that grammar is again at state in which it is considered an essential element of language teaching and the focus of institutes on grammar can prove this.

2. Why is grammar taught?

As cited in Nachiengmai, 1997, many linguists and researchers have given support to grammar instruction in ESL and EFL language teaching and learning. for example, the communicative competence model of Canale and swain (1980) clearly illustrates the significance of grammar in this model that grammar is viewed as one component of communicative competence. Actually, Without grammar learners maybe can communicate effectively only in a limited number of situations but it does not mean that they have learned the language perfectly. In addition, Hannan (1989), Lewis (1986) and Garner (1989) strongly support the teaching of grammar. According to Hannan (1989), grammar is highly valuable as an important part of the study of language of ideas, and of writing. Besides, he points to understand the diversity of human culture. (As cited in Nachiengmai, 1997).

As cited in Nachiengmai, 1997, Garner (1989) believes that grammar gives us a means to analyze and describe our language.

\section{RESEARCH QUESTIONS AND HYPOTHESIS}

Due to the fact that English language plays an important role as a second language in educational curriculum of Iran, and special attention is given to by people, the findings of the present study can be both theoretically and practically significant. Such a study provides information to be taken into consideration by teachers as well as learners and their parents. Hopefully the results of the study will be useful for both EFL and ESL learners and teachers. Finding any possible relationship among logical- linguistic, and naturalist intelligences and learning grammar provide us with opportunities to look differently at the curriculum, Instruction and assessment. Thus, this study aims investigating the relationship among the two mentioned intelligences and learning grammar on EFL students in Elementary level.

Based on the objective of the study, the following research questions were proposed;

1. Is there any relationship between learning grammar and logical intelligence?

2. Is there any relationship between learning grammar and naturalistic intelligence?

A. Research Hypothesis

1. There is no relationship between learning grammar and logical intelligence.

2. There is no relationship between learning grammar and naturalistic intelligence.

\section{METHODOLOGY}

The purpose of this study was answer the following questions:

1. Is there any relationship between learning grammar and logical intelligence?

2. Is there any relationship between learning grammar and naturalistic intelligence?

\section{A. Participants}

A total of thirty Iranian EFL learners (twenty girls, ten boys), studying the Interchange Intro book( Jack C. Richards, 2005) at Golestan Language Institute (Simin Tehran Central Branch, Mashhad, Iran), were selected and asked to participate in this study. The students were selected randomly so the age was not considered in this study.

\section{B. Instruments}

This study was aimed to find out the relationship among two types of multiple intelligences (logical and naturalistic) and learning grammar, thus two kinds of instruments were used to observe the result.

\section{Multiple Intelligence Questionnaire}

In order to measure the students' MI, Multiple Intelligence Developmental Assessment Scale (MIDAS) questionnaire (Shearer, 1996; cited in Hosseini, 2003) was used. Indeed, a 119- Item questionnaire in native language, has been translated by Hosseini (2003) from English to Persian, measuring the nine types of intelligences given as the first instrument of the study. The total reliability of the questionnaire was 0.94. An estimated time for taking the test was 50-60 minutes.

\section{Grammar Multiple - Choice Test}

A forty- item grammar multiple- choice test based on the Interchange Intro book( Jack C. Richards, 2005), was planned for the students, and the time determined for this test was about thirty minutes. Moreover, this test was prepared by the researcher and based on the table of specification of the mentioned book ( shown in Appendix). The tested reliability was 0.84 .

\section{Procedure}

In this research thirty subjects were chosen including male and female. In fact, ten boys and twenty girls who were in elementary level in Golestan Language Institute in Mashhad, took part in this research. In order to find out the relationship among logical, linguistic, and naturalistic intelligences and learning grammar, two kinds of tests were given 
to students (i.e.) a 119- item multiple intelligence test and a forty-item multiple - choice grammar test. The estimated time for completing the tests were 50-60 and 30 minutes respectively.

Finally, each student's test was graded separately and through the Pearson correlation the results were achieved as follows.

\section{RESULTS AND CONCLUSION}

\section{A. Learning Grammar and Multiple Intelligence}

The following table shows the mean, variance, low score, and the high score of both multiple-choice grammar and multiple intelligences test.

TABLE 1:

MEAN, VARIANCE, LOW SCORE, AND THE HIGH SCORE OF THE RELATED TESTS

\begin{tabular}{|c|c|c|}
\hline \multicolumn{3}{|c|}{ Male's statistics } \\
\hline & grammar & intelligence \\
\hline Mean & 26.30 & 46.7000 \\
\hline Variance & 51.789 & 50.098 \\
\hline Low score & 16 & 37.62 \\
\hline High score & 38 & 56.88 \\
\hline
\end{tabular}

\begin{tabular}{|c|c|c|}
\hline \multicolumn{3}{|c|}{ Female's statistics } \\
\hline & grammar & intelligence \\
\hline Mean & 25.85 & 46.4625 \\
\hline Variance & 46.871 & 41.862 \\
\hline Low score & 14 & 34.62 \\
\hline High score & 36 & 56.62 \\
\hline
\end{tabular}

Based on the above-mentioned table, The average level of boys' intelligence was found to be 46.7 while it was 46.4 in girls. The lowest intelligence scores were 37.62 and 34.4 in boys and girls respectively, in contrast to the highest intelligence scores which were 56.8 in boys and 56.6 in girls. The mean of grammar scores in boys and girls were 26.3 and 25.8 respectively. The variance of boys' intelligence was found to be 50.0 which shows more dispersion in the scores in comparison with that of girls that was 41.86 .

TABLE 2:

THE RELATIONSHIP BETWEEN LEARNING GRAMMAR AND THE MULTIPLE INTELLIGENCES

\begin{tabular}{|c|c|c|c|c|}
\hline \multicolumn{3}{|c|}{ Correlations } & \multirow{3}{*}{$\begin{array}{l}\text { Grammar } \\
.659^{*}\end{array}$} & \multirow{3}{*}{$\begin{array}{l}\text { intelligence } \\
1\end{array}$} \\
\hline & & & & \\
\hline \multirow[t]{5}{*}{ Males } & \multirow[t]{3}{*}{ intelligence } & Pearson correlation coefficient & & \\
\hline & & Significance level & .038 & \\
\hline & & Numbers & 10 & 10 \\
\hline & \multirow[t]{2}{*}{ grammar } & Pearson correlation coefficient & 1 & $.659^{*}$ \\
\hline & & Significance level & & .038 \\
\hline \multirow[t]{5}{*}{ Females } & \multirow[t]{3}{*}{ intelligence } & Pearson correlation coefficient & -.093 & 1 \\
\hline & & Significance level & .698 & \\
\hline & & Numbers & 20 & 20 \\
\hline & \multirow[t]{2}{*}{ grammar } & Pearson correlation coefficient & 1 & -.093 \\
\hline & & Significance level & & .698 \\
\hline
\end{tabular}

*. Correlation is significant at the 0.05 level (2-tailed

According to Pearson correlation coefficient, there is a significant relationship between boys' levels of intelligence and their grammar scores.

The correlation coefficient of 0.65 indicates a strong and positive relationship and the significance level of 0.03 confirms the validity of the test with a certainty level of $97 \%$. But no significant relationship was found between girls' intelligence and their grammar scores.

B. Learning Grammar And Logical And Naturalistic Intelligences 
TABLE 1:

MATH-LOGICAL INTELLIGENCE

\begin{tabular}{|c|c|c|c|c|}
\hline \multirow{2}{*}{\multicolumn{5}{|c|}{ Correlations }} \\
\hline & & & & \\
\hline \multirow[t]{6}{*}{ Males } & \multirow[t]{3}{*}{ Grammar } & Pearson correlation coefficient & $.636^{*}$ & 1 \\
\hline & & Significance level & .048 & \\
\hline & & Numbers & 10 & 10 \\
\hline & \multirow{3}{*}{$\begin{array}{l}\text { Logical } \\
\text { intelligence }\end{array}$} & Pearson correlation coefficient & 1 & $.636^{*}$ \\
\hline & & Significance level & & .048 \\
\hline & & Numbers & 10 & 10 \\
\hline \multirow[t]{6}{*}{ Females } & \multirow[t]{3}{*}{ grammar } & Pearson correlation coefficient & -.105 & 1 \\
\hline & & Significance level & .661 & \\
\hline & & Numbers & 20 & 20 \\
\hline & \multirow{3}{*}{$\begin{array}{l}\text { Logical } \\
\text { intelligence }\end{array}$} & Pearson correlation coefficient & 1 & -.105 \\
\hline & & Significance level & & .661 \\
\hline & & Numbers & 20 & 20 \\
\hline
\end{tabular}

*. Correlation is significant at the 0.05 level (2-tailed).

While a positive and significant relationship was found between boys' grammar and logical intelligence scores, no strong relationship was found between these two scores in girls.

The correlation coefficient in boys' logical intelligence scores was 0.63 at the significance level of 0.04 . The negative correlation coefficient in girls shows there was no relationship between these two variables. But the significance level of 0.6 does not confirm this relationship statistically.

TABLE 2:

NATURALIST INTELLIGENCE

\begin{tabular}{|c|c|c|c|c|}
\hline \multirow{2}{*}{\multicolumn{3}{|c|}{ Correlations }} & \multirow{3}{*}{$\begin{array}{l}\begin{array}{l}\text { Naturalist } \\
\text { intelligence }\end{array} \\
.820^{* * *} \\
\end{array}$} & \multirow{3}{*}{$\begin{array}{l}\text { grammar } \\
1 \\
\end{array}$} \\
\hline & & & & \\
\hline \multirow[t]{6}{*}{ Males } & \multirow[t]{3}{*}{ Grammar } & Pearson correlation coefficient & & \\
\hline & & Significance level & .004 & \\
\hline & & Numbers & 10 & 10 \\
\hline & \multirow{3}{*}{$\begin{array}{l}\text { Naturalist } \\
\text { intelligence }\end{array}$} & Pearson correlation coefficient & 1 & $.820^{* *}$ \\
\hline & & Significance level & & .004 \\
\hline & & Numbers & 10 & 10 \\
\hline \multirow[t]{6}{*}{ Females } & \multirow[t]{3}{*}{ grammar } & Pearson correlation coefficient & -.192 & 1 \\
\hline & & Significance level & .417 & \\
\hline & & Numbers & 20 & 20 \\
\hline & \multirow{3}{*}{$\begin{array}{l}\text { Naturalist } \\
\text { intelligence }\end{array}$} & Pearson correlation coefficient & 1 & -.192 \\
\hline & & Significance level & & .417 \\
\hline & & Numbers & 20 & 20 \\
\hline
\end{tabular}

There is meaningful, positive, and strong relationship between naturalist intelligence scores and grammar among male students. Thus we can say that the more students are naturalist, the more their grammar score is.

These two variables with a zero coefficient represent the converse and very weak relationship among female students. But the meaningful level which is 0.4 , doesn't confirm this fact. So there is no confirmed relationship between the scores of two variables among females.

The main objectives of this study were to explore two types of multiple intelligences (logical and naturalistic) and the relationship between them and learning grammar. The subjects of this study were thirty EFL male and female elementary students of English, studying Interchange Intro book in Golestan language institute. The research was conducted through a 119- item multiple intelligence questionnaire and a forty item multiple choice grammar test. As you saw in the previous chapter, the results were shown according to Pearson analytical method. This chapter consists of a discussion regarding the results and pedagogical implications which shows the effect of conducting this study in education and teaching.

The study has answered the research question and arrived at the result that there is no significant relationship between the two types of multiple intelligences and learning grammar among girls, whereas a strong and positive relationship was found among boys, implying that the ability, understanding underlying principles (math-logical intelligence), and discriminating among living things such as plants and animals as well as sensitivity to other features of the natural world (naturalist intelligence), has a strong relationship with learning grammar. Of the two confirmed intelligences, naturalistic type was found to be the leading intelligence, and math-logical type was the least common one employed by the students who participated in this study. 
Nowadays, one of the most hotly debated topics in EFL language teaching and learning is Grammar. As cited in Nachiengmai, 1997, many linguists and researchers have given support to grammar instruction in ESL and EFL language teaching and learning. For example, the communicative competence model of Canale and swain (1980) clearly illustrates the significance of grammar in this model. In this model, as cited in Nachiengmai, 1997, grammar is viewed as one component of communicative competence. Without grammar learners can communicate effectively only in a limited number of situations. In addition Hannan (1989), Lewis (1986) and Garner (1989) strongly support the teaching of grammar but maybe they will fail to understand others. (As cited in Nachiengmai, 1997). According to Hannan (1989), as cited in Nachiengmai, 1997, grammar is highly valuable as an important part of the study of language of ideas, and of writing. Besides, he points out that through using of grammar, you are able to understand the diversity of human culture.

As the findings of the study suggest, gender has a significant role in learning grammar. Furthermore, a significant relationship was found between naturalist intelligence and learning grammar. So, it is a factor which needs to be considered in teaching grammar.

\section{REFRENCES}

[1] Ahmadian, M., \& Hosseini, S. (2012). A Study of the Relationship Between Iranian EFL Learners' Multiple Intelligences and their Performance on Writing. Mediterranean Journal of Social Sciences. 3.1, 111-126.

[2] Brualdi, A, C. (1996). 'Multiple Intelligences: Gardner's Theory. ERIC Digest', Eric Digests, http://www.ericdigests.org/19981/multiple.htm. (Accessed 15/6/2008).

[3] Dening, S.J. (2004). Multiple Intelligences and Learning Styles: Two Complementary Dimensions. Teachers College Record. 106.1, 96-111.

[4] Gardner, H., \& Hatch, T. (1989 a). Multiple intelligences go to school: Educational implications of the theory of multiple intelligences. Educational Researcher, 18.8, 4-9.

[5] Gardner, H., \& Hatch, T. (1989 b). Multiple intelligences go to school: Educational implications of the theory of multiple intelligences. Educational Researcher, p.4-10. retrieved 2013 from JSTOR.

[6] Gardner, H. (1993 c). Multiple intelligences: The theory in practice. New York: Basic Books.

[7] Gardner, H \& Hatch, T. (1993 d). 'Finding cognition in the classroom: an expanded view of human intelligence' in G. Salomon (ed.) Distributed Cognitions. Psychological and educational considerations, Cambridge: Cambridge University Press.

[8] Gardner, H. (2006 e). Changing Minds. The art and science of changing our own and other people's minds. Boston MA: Harvard Business School Press.

[9] Helding, L. (2009). "Howard Gardner's Theory of Multiple Intelligences", Journal of Singing. 66.2, 193-199.

[10] Hosseini, C. (2003). The relationship between Iranian EFL students' multiple intelligences and their use of language learning strategies. Unpublished M.A. thesis, Tarbiat Modarres University, Tehran, Iran.

[11] Nachiengmai, Y. (1997). The Teaching Of Grammar, ThaiTESOL Bulletin. 10.2.

[12] Panahi, A. (2011). Relationship between multiple intelligences and learning grammar in EFL setting. Iranian EFL Journal. 7.5, 139-163.

[13] Puchta, H. \& Rinvolucri, M. (2009). Multiple Intelligences in EFL Exercises for secondary and adult students. Journal of Theory and Practice in Education Articles. 5.2, 110-122.

[14] Saricoglu, A. (2008). The effect of the relationship between learning and teaching strategies on academic achievement. Novitas-ROYAL. 2.2, 162-175.

[15] Scherer, M. (1999). 'The Understanding Pathway: A Conversation with Howard Gardner', Educational Leadership. 57(3) www.georgejacobs.net/MIArticles/Gardner\%20ASCD\%201999.doc. (Accessed 15/6/2008).

[16] Sternberg, R. J. (1985). Beyond IQ: A triarchic theory of human intelligence. New York: Cambridge University Press.

[17] Williams, W. M., Blythe, T., White, N., Li, J., Sternberg, R. J., \& Gardner, H. (1996). Practical intelligence for school. New York: HarperCollins College Publishers.

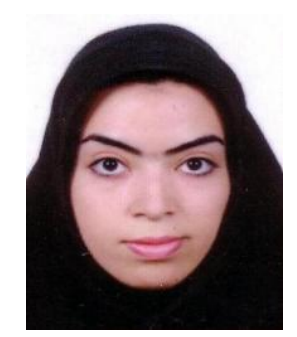

Zeinab Zahedi Born in Mashhad, Iran on 1990/5/8. She received her BA in English Language Translation from Binaloud University of Mashhad, Iran. (summer, 2013)

She is MA student of English Language Teaching in Ferdowsi University of Mashhad, Iran.

She has gotten accepted for MA without any entrance exam and based on the average point. She has been teaching English in different institutes of Mashhad, Iran since 2009 till now. She has teaching experiences in high schools and Tarbiat Moalem University. 


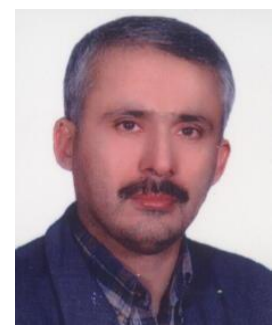

Zargham Ghabanchi born in Khorramshahr, Iran on 1961/12/9. He received his BA in English Language and Literature from Mashhad University, Iran.

He received his MA in TEFL from Tehran Tarbiyyat Modarres University, Iran.

He started his Ph.D at the University of Liverpool, the UK in 1993 and Ph.D was conferred to him in 1998 in Applied Linguistics. Now he has a chair at Sabzevar Teacher Training University, and he is vice chancellor of Sabzevar Payam Noor University. He has published several books and articles. 